\title{
Using high-resolution phosphorus data to investigate mitigation measures in headwater river catchments
}

\author{
J. M. Campbell, P. Jordan, and J. Arnscheidt \\ School of Environmental Sciences, University of Ulster, Coleraine, Northern Ireland, BT52 1SA, UK \\ Correspondence to: J. M. Campbell (jm.campbell@ulster.ac.uk)
}

Received: 22 August 2014 - Published in Hydrol. Earth Syst. Sci. Discuss.: 30 September 2014

Revised: - - Accepted: 29 December 2014 - Published: 26 January 2015

\begin{abstract}
This study reports the use of high-resolution water quality monitoring to assess the influence of changes in land use management on total phosphorus (TP) transfers in two $5 \mathrm{~km}^{2}$ agricultural sub-catchments. Specifically, the work investigates the issue of agricultural soil $\mathrm{P}$ management and subsequent diffuse transfers at high river flows over a 5-year timescale. The work also investigates the phenomenon of low flow P pollution from septic tank systems (STSs) and mitigation efforts - a key concern for catchment management. Results showed an inconsistent response to soil P management over 5 years with one catchment showing a convergence to optimum $\mathrm{P}$ concentrations and the other an overall increase. Both catchments indicated an overall increase in $\mathrm{P}$ concentration in defined high flow ranges. Low flow $\mathrm{P}$ concentration showed little change or higher $\mathrm{P}$ concentrations in defined low flow ranges despite replacement of defective systems and this is possibly due to a number of confounding reasons including increased housing densities due to new-builds. The work indicates fractured responses to catchment management advice and mitigation and that the short to medium term may be an insufficient time to expect the full implementation of policies (here defined as convergence to optimum soil $\mathrm{P}$ concentration and mitigation of STSs) and also to gauge their effectiveness.
\end{abstract}

\section{Introduction}

With the introduction of the European Union (EU) Water Framework Directive (OJEC, 2000), and similar international legislation that seeks to improve and maintain the water quality of rivers, lakes and coastlines, assessing the magnitude of nutrient losses from agricultural catchments has become a priority (Cherry et al., 2008). Phosphorus (P) is particularly related to eutrophication problems in freshwaters and is prioritised in certain states for mitigation (Wall et al., 2011; Hirsch, 2012). Despite this requirement, an equally important need is to maintain a healthy agri-economy which depends on $\mathrm{P}$ inputs to catchments.

The $\mathrm{P}$ transferred from agricultural catchments can be from diffuse and/or point sources and in recent years the role of septic tank systems (STSs), as rural point sources, has been identified in elevating low flow P concentrations (Withers et al., 2012, 2014). The flow paths taken from source to impact point are affected by the complexity of catchments at both temporal and spatial scales (Turcotte, 1997; Kirchner et al., 2004) resulting in river $P$ that has dependencies and signals according to hydrological conditions (Jordan et al., 2007a).

Low-resolution grab sampling for chemical parameters remains the norm for most river monitoring programmes, at least in the European Union (EU) (Bowes et al., 2009). However, it is recognised that in order to completely understand the full range of river chemical signals, which are influenced by catchment processes and entrained in the range of river discharges, higher resolution monitoring is preferred (Palmer-Felgate et al., 2008; Harris and Heathwaite, 2012).

The use of bankside analysers is a relatively recent stepped change in technology for high-resolution $\mathrm{P}$ monitoring of both diffuse and point source signals. Jordan et al. (2005a, 2007a) used this technology in the border area of Ireland to provide a typology of river $\mathrm{P}$ transfers. Arnscheidt et al. (2007) used data from the same sub-catchments to define the sources of low flow P transfers. Several other studies have also used bankside analysis to define the magnitude of $\mathrm{P}$ transfers from point and diffuse sources at diurnal, event, 
seasonal and annual scales (Palmer-Felgate et al., 2008; Melland et al., 2012; Wade et al., 2012; Donn et al., 2012).

However, despite these innovations and increased understanding of $\mathrm{P}$ dynamics in rivers, there has been no reported use of high-resolution data sets to monitor the influence of catchment change on river $\mathrm{P}$ patterns. Other workers, using coarser resolution data, have proposed Load Apportionment Models to determine changes in the proportions of point and diffuse $\mathrm{P}$ transfers using assumptions based on relationships between discharge and P concentration (Greene et al., 2011). Major limitations of this method include the reliance on sparse concentration data at the high end of discharge records (Bowes et al., 2008).

In this investigation, a method is used to detect catchment change influences on $\mathrm{P}$ transfer which integrates all the discharge-P concentration patterns that might occur, in toto, during different stages of river discharges including low and storm flows. The method is applied to a 5-year P and discharge data set in two agricultural sub-catchments which were subject to a series of voluntary (soil P) and mandatory (closed periods for fertiliser/slurry application) management regimes and changes to STSs and monitored between 2006 and 2011. This study sought to assess if there was an improvement in chemical water quality in the sub-catchments as a result of changes in management regimes and the implementation of a series of mitigation measures.

\section{Study area}

The study areas for this project were two $5 \mathrm{~km}^{2}$ subcatchments in Co. Monaghan and Co. Tyrone in the Irish border area (Fig. 1). These are situated on two major tributaries, the Mountain Water and Oona Water, (respectively) of the Blackwater River, which has a cross border catchment $\left(1480 \mathrm{~km}^{2}\right)$. The Blackwater is the largest catchment of the six rivers which flow into the hypertrophic Lough Neagh (Griffiths, 2007).

Land use is $90 \%$ agricultural with mixed livestock (beef, dairy and sheep enterprises in order of importance) (Land cover 2000 classification) and a stocking density of 1.5 LU ha ${ }^{-1}$ (livestock unit per hectare). The sub-catchments had a rural population density in 2005 of 13.8 and 3.4 households $\mathrm{km}^{-2}$ in Co. Monaghan and Co. Tyrone, respectively, with an average household size of 3 persons (Arnscheidt et al., 2007).

The underlying geology is mostly Carboniferous (Dinantian) sandstones, limestone, shale and mudstones (Cruickshank, 1997) overlaid by a till of pro-glacial boulder clay forming drumlins and Rogën moraines (Knight et al., 1999). These boulder clays effectively inhibit surface and ground water interactions resulting in isolated aquifers (O’Dochartaigh, 2003). Soils are, therefore, poorly drained with a seasonally perched water table resulting in winter saturation excess overland flow following heavy rains (Kane, 2009). The rainfall in both catchments is $800-1200 \mathrm{~mm} \mathrm{yr}^{-1}$,

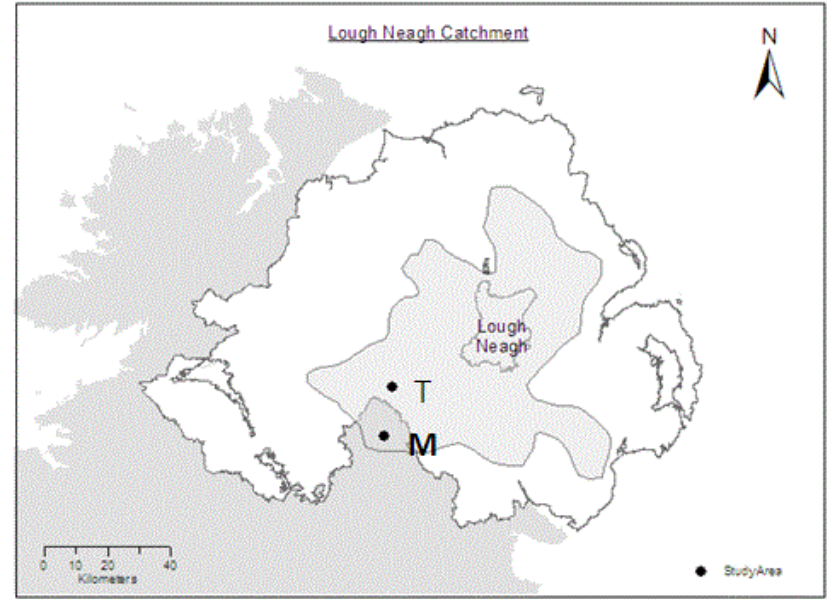

Figure 1. Map of Northern Ireland and part of the Republic of Ireland showing the Lough Neagh catchment and location of Co. Tyrone (T) and Co. Monaghan (M) study areas.

the upper end of which is above average for this part of Ireland, based on the current 30-year average (Met Eirann, Clones, Co. Cavan).

The hydrology of the soil is driven by high run-off rates, low water storage capacity, perched water tables and low permeability (Jordan et al., 2007b). These hydrological factors combine to create fast run-off pathways during storm events leading to increased diffuse pollution risk. In addition to this, the lack of water storage capacity suppresses summer base flows and increases point source pollution risk.

\section{Methods}

\subsection{Surveys}

Three surveys were conducted in this study; soil P status and changes, which were subsequently mapped; septic tank system changes; and P concentration delivered to stream systems using a semi-continuous high-resolution approach.

\subsection{Soil phosphorus surveys}

Between December 2004 and February 2005 composite soil samples were taken from 170 fields in the Co. Monaghan sub-catchment and 276 fields in the Co. Tyrone subcatchment, following a reasonable period since the application of organic/inorganic fertiliser to ensure soil $\mathrm{P}$ equilibrium (6 weeks: Agbenin and Tiessen, 1995); this represented 62 and $69 \%$ by land area, respectively. The composites consisted of thirty sub-samples that were randomly extracted to $7.5 \mathrm{~cm}$ depth from each field using a soil corer and across a "W" pattern in order to allow for heterogeneity of soil nutrient status at intra-field scale, but avoiding areas where animals would have sheltered or congregated close to 
feeding troughs. The composite samples were prepared for analysis by air drying and sieving through a $2 \mathrm{~mm}$ mesh. Plant available Olsen-P concentrations were determined on $5 \mathrm{~cm}^{3}$ samples in both catchments and, in accordance with standard soil P testing methods for the Republic of Ireland in Co. Monaghan, plant available Morgan-P concentration (Olsen et al., 1954; Morgan, 1941). Nutrient management plans were provided to farmers on a field basis and based on respective requirements for optimum grassland agriculture in each catchment and jurisdiction (equivalent to SI 31, 2014 and SRNI 488, 2006). Of the farmers participating, formal nutrient management plans were either a new concept or had been previously provided at the very coarse scale with several field blocks integrated as single land use units.

Between December 2009 and February 2010 a percentage of the same fields was resampled and analysed to assess any change in soil nutrient concentration subsequent to nutrient management recommendations. Sampling fewer fields was necessary due to budget and time constraints. The resample percentage size was determined using an a priori Monte Carlo power analysis, using a $5 \%$ possible change as a realistic value based on the time between samples and a zero $\mathrm{P}$ application rate (Watson et al., 2007), to compute the minimum sample size required to be confident in detecting a change in soil concentration. Therefore, 91/170 and 143/276 fields, approximately $53 \%$ of the original number, were re-sampled in Co. Monaghan and Co. Tyrone, respectively.

The soil nutrient data were mapped using GIS (ArcGIS v10) and calculations made of the length of stream in each catchment which was potentially impacted by bankside soils with $\mathrm{P}$ concentrations which were well above the Olsen agronomic optimum i.e. soils at index $4>45 \mathrm{mg} \mathrm{PL}^{-1}$ (according to RB209; MAFF, 2000). Such sites, recognised as having a high $\mathrm{P}$ transport potential, are known as critical source areas (CSAs) and, although they may have a low proportion of the catchment area, can contribute a majority of annual P loss (Sharpley and Reikolainen, 1997).

\subsection{Septic tank system surveys}

In a companion study, STSs were surveyed, ranked and a subset chosen for mitigation. The results of this study are largely reported by Macintosh et al. (2011) although the Co. Tyrone catchment and a more detailed analysis are included (with the Co. Monaghan catchment) in the present study.

\subsection{Water quality}

In 2005 Hach-Lange Phosphax and Sigmatax bankside analyser stations were installed in kiosks at the outlet of the sub-catchments (Jordan et al., 2005a). The bankside analyser takes a $100 \mathrm{~mL}$ sample and determines total phosphorus (TP) on a default 20 minute cycle. The sample is homogenised with ultrasonic pulses for approximately $120 \mathrm{~s}$ before a $10 \mathrm{~mL}$ sub-sample is extracted and superheated with sulfuric acid and sodium peroxydisulfate. The TP concentration is then determined photometrically using the method of Eisenreich et al. (1975). Regular calibration and analytical checks were carried out in conjunction with the automated analysis and weekly maintenance was carried out to ensure optimum suite performance (Cassidy and Jordan, 2011). Details of a quality control study were also included in the present investigation with TP samples analysed in the laboratory from stream samples immediately adjacent to the Sigmatax intake and also samples from the Sigmatax homogenisation jar (prior to Phosphax sub-sampling). These tests were designed to test the robustness of both the Sigmatax sample collection stage and also the Phosphax digestion and colorimetric stages. Total P was deemed an appropriate parameter for analysis in these catchments as previous studies had highlighted a process of fast entrainment of soluble $\mathrm{P}$ to particulate $\mathrm{P}$ owing to high iron and aluminium sources and transfers (Jordan et al., 2005b; Douglas et al., 2007).

River discharges were recorded using an OTT Thalimedes, measuring stage height at $1 \mathrm{~min}$ intervals and recording the average over 15 mins. Stage heights were converted to discharge $\left(\mathrm{m}^{3} \mathrm{~s}^{-1}\right)$ using a rating curve that was constructed for each stream by measuring discharge over a range of stage heights above controls using the velocity area method. Velocity was measured using an OTT Nautilus electromagnetic flowmeter and a Streampro ADCP. Rainfall was monitored at both sites using an ARG-100 gauge but not over the full record in Co. Monaghan.

\subsection{Data analysis}

Having determined normality of the soil test $\mathrm{P}$ data, all changes in potential soil $\mathrm{P}$ test concentration were assessed using a two-tailed matched pair $t$ test. Olsen-P results were compared based on whole catchment, farm block, soil $\mathrm{P}$ index and individual field status. The assumption here is that, as no $\mathrm{P}$ fertiliser was being applied to fields where there was found to be an excess in the 2005 testing, both catchments would see a reduction in soil $\mathrm{P}$ concentrations and a convergence on an optimum index equivalent to Olsen 16-25 $\mathrm{mg} \mathrm{P} \mathrm{kg}^{-1}$ (Morgan 5-8 $\mathrm{mg} \mathrm{P} \mathrm{L}^{-1}$ ). The indices considered were $0\left(0-9 \mathrm{mg} \mathrm{P} \mathrm{kg}^{-1}\right), 1$ (10$\left.15 \mathrm{mg} \mathrm{P} \mathrm{kg}^{-1}\right), 2$ (16-25 mg P kg$\left.{ }^{-1}\right), 3$ (26-45 $\left.\mathrm{mg} \mathrm{P} \mathrm{kg}^{-1}\right)$ and $>4\left(>46 \mathrm{mg} \mathrm{P} \mathrm{kg}^{-1}\right)$.

The data from the bankside analysers in both catchments for the five hydrological years (determined as two water-half years), April 2006-March 2011, were extracted and, prior to analysis, were screened. Erroneous values were removed and the completeness of the data was determined. Once the data for each year had been cleaned hourly averages for each parameter were calculated and load $\left(\mathrm{kg} \mathrm{Pha}^{-1}\right)$ was reported as a product of the hourly discharge and its associated TP concentration.

The discharge data from the continuous time series were ranked and the discharge ranges for each catchment were ex- 
tracted from $Q_{5}-Q_{95}$ in a flow-duration curve. The method of comparison over the 5-year period was to identify similar discharge ranges in each year corresponding to the discharge range, and extract the concurrent $\mathrm{P}$ concentration data. Following tests of normality (Lloyd et al., 2014), the mean and variance of TP concentrations, for each discharge range, were compared in a year on year basis by one-way ANOVA in order to determine the magnitude and significance of any change.

Low and extreme-low flow $\mathrm{P}$ concentration changes were investigated in $Q_{90}-Q_{80}$ and $Q_{95}-Q_{90}$ discharges ranges, respectively. These ranges, below which for example, $20 \%$ of the record fell, were deemed most likely to show a TP influence from rural point sources (Withers et al., 2012). Additionally, previous studies on the catchments (Douglas et al., 2007) had shown that $>70 \%$ of the annual $P$ load can occur at $Q_{10}$ or greater; the infrequent high flows above $90 \%$ of the record. For this reason part of the study focuses on the $Q_{50}$ and above, the higher flows above $50 \%$ of the record, during which the majority of the annual P load were deemed to be delivered from the catchments. These were extracted as $Q_{40}-Q_{50}, Q_{20}-Q_{30}$ and $Q_{5}-Q_{10}$ discharges.

As total annual $\mathrm{P}$ load is highly influenced by annual discharge (Edwards and Withers, 2007), which varies with climate (rainfall) variability, it was assumed that this metric (annual $\mathrm{P}$ load) would be an unreliable predictor of change if catchment mitigation strategies had influenced $\mathrm{P}$ in run-off in the short term. Nevertheless, the metric was calculated so the overall magnitude, and subsequent downstream risk, of these sub-catchment $P$ exports could be compared with others.

\section{Results}

\subsection{Soil phosphorus changes}

When soil P concentrations were compared for each subcatchment (Table 1a and b) the fields in Co. Tyrone showed a small and non-significant increase in Olsen-P concentration across all soil indices (expressed using the Olsen data) between 2005 and 2010, whereas an increase in Co. Monaghan was larger and significant; $1.6 \mathrm{mg} \mathrm{PL}^{-1}(P=0.1, n=143)$ and $5.7 \mathrm{mg} \mathrm{PL}^{-1}\left(P=0.9 \times 10^{-4}, n=91\right)$ in Co. Tyrone and Co. Monaghan, respectively.

On an index basis in Co. Tyrone over the 5-year period, the index 1 and 2 fields showed a significant increase in mean $\mathrm{P}$ concentration from 16.28 to $22.24 \mathrm{mg} \mathrm{P} \mathrm{L}^{-1}$ $\left(P=0.161 \times 10^{-10}, n=78\right)$. However, when all fields with 2005 concentration $>26 \mathrm{mg} \mathrm{PL}^{-1}$ (index 3 and above) were analysed for change there was a significant decrease from 41.8 to $37.7 \mathrm{mg} \mathrm{PL}^{-1}(P=0.008, n=65)$. When only fields with a 2005 concentration $>46 \mathrm{mg} \mathrm{PL}^{-1}$ (index 4 and above) were considered there was also a significant mean decrease from 56.0 to $48.9 \mathrm{mg} \mathrm{PL}^{-1}(P=0.045, n=30)$.
Table 1. Summary of change in Olsen-P concentration for all soil indices in the Co. Tyrone (a) and Co. Monaghan (b) subcatchments.

\begin{tabular}{|c|c|c|c|c|}
\hline Catchment & $\begin{array}{l}\text { Olsen-P } \\
\text { index }\end{array}$ & $\begin{array}{l}\text { Mean change } \\
\text { in Olsen-P } \\
\text { conc. mg P/L }\end{array}$ & $\begin{array}{l}\text { Matched pairs } \\
\text { two tailed } \\
t \text { test } \\
P \text { value }\end{array}$ & $\begin{array}{l}\text { No. of } \\
\text { fields }\end{array}$ \\
\hline \multicolumn{5}{|c|}{ (a) } \\
\hline Co. & $1,2,3,4$ & 1.6 & 0.1 & 143 \\
\hline \multirow[t]{3}{*}{ Tyrone } & 1,2 & 5.96 & $1.61 \times 10^{-9}$ & 78 \\
\hline & 3,4 & -4.1 & 0.008 & 65 \\
\hline & 4 & -7.2 & 0.045 & 30 \\
\hline \multicolumn{5}{|c|}{ (b) } \\
\hline Co. & $1,2,3,4$ & 5.7 & $0.9 \times 10^{-4}$ & 91 \\
\hline \multirow[t]{3}{*}{ Monaghan } & 1,2 & 7.1 & $0.8 \times 10^{-3}$ & 32 \\
\hline & 3,4 & 4.5 & 0.01 & 59 \\
\hline & 4 & 4.9 & 0.033 & 27 \\
\hline
\end{tabular}

The Co. Monaghan soil $\mathrm{P}$ changes reflected the same pattern as Co. Tyrone in the lower index fields 1 and 2; there was a significant increase from a mean value of 19.8 to $26.9 \mathrm{mg} \mathrm{P} \mathrm{L}^{-1}\left(P=0.8 \times 10^{-3}, n=32\right)$. Unlike Co. Tyrone, however, the higher index fields in Co. Monaghan showed an increase in mean concentration. For example, between 2005 and 2010 the mean concentration rose significantly from 46.2 to $50.7 \mathrm{mg} \mathrm{PL}^{-1}$ for index 3 and above $(P=0.01$, $n=59$ ). When only index 4 and above fields were considered there was a mean increase of 56.4 to $61.3 \mathrm{mg} \mathrm{PL}^{-1}$ $(P=0.033, n=27)$.

\subsection{Critical source areas}

Despite both catchments having the same area $\left(5 \mathrm{~km}^{2}\right)$ and similar agricultural management, the soil survey carried out in 2010 determined that the percentage of fields in the Co. Monaghan sub-catchment with index 4 and above was higher than in Co. Tyrone. Furthermore, the adjacent location of these high index fields in relation to the stream network (Fig. 2a and b) was higher in Co. Monaghan $(2552 \mathrm{~m}$ of the $36852 \mathrm{~m}$ total stream network $-6.9 \%)$ than Co. Tyrone $(724 \mathrm{~m}$ of the $19375 \mathrm{~m}$ total stream network $-3.7 \%$ ) (Table 2).

\subsection{Phosphax quality control}

The results of the quality control investigation of the Sigmatax and Phosphax stages are shown in Fig. 3. The subsamples extracted from the homogenisation jar prior to the Phosphax stage, and analysed using standard laboratory techniques, are in very close agreement $\left(b=0.97 ; R^{2}=0.98\right)$ with the Phosphax measurements. This is essentially the same parcel of sampled water analysed by two techniques but using the same method (acid digestion and colorimetry) and indicating $97 \%$ recovery. The same Phosphax measure- 
Table 2. Length of stream network potentially impacted in each catchment by Olsen-P index 4 fields (critical source areas).

\begin{tabular}{lccrc}
\hline Sub-catchment & $\begin{array}{c}\text { Percentage } \\
\text { of catchment } \\
\text { fields Olsen-P } \\
\text { index } \geq 4\end{array}$ & $\begin{array}{c}\text { Length of } \\
\text { stream network } \\
(\mathrm{m})\end{array}$ & $\begin{array}{r}\text { Length of } \\
\text { stream network } \\
\text { impacted by } \\
\text { high index } \\
\text { fields (m) }\end{array}$ & $\begin{array}{c}\text { Percentage } \\
\text { stream network } \\
\text { impacted by high } \\
\text { index fields }\end{array}$ \\
\hline Co. Tyrone & 21 & 19375 & 724 & 3.7 \\
Co. Monaghan & 29 & 36852 & 2552 & 6.9 \\
\hline
\end{tabular}

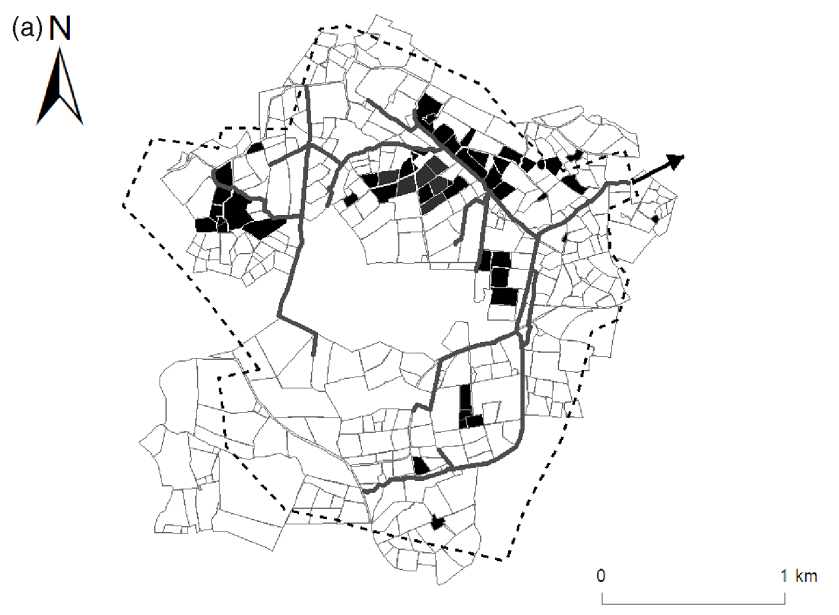

(b)

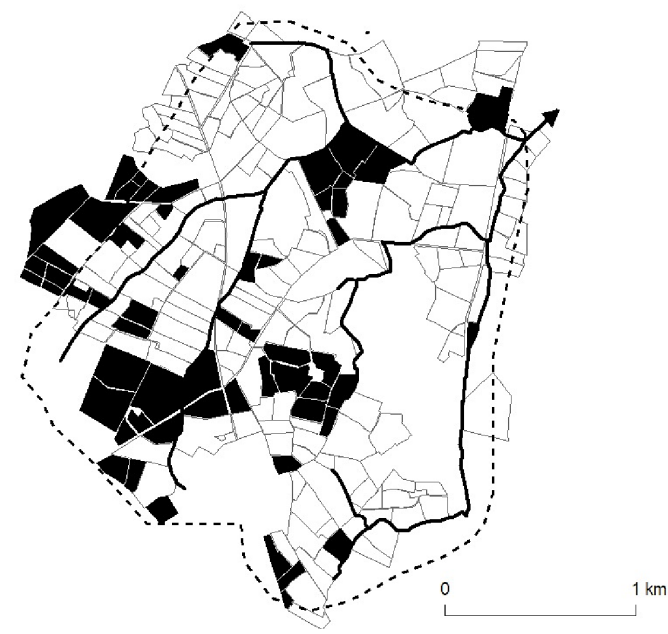

Figure 2. Location of index 4 fields in the Co. Tyrone (a) and Co. Monaghan (b) sub-catchments (dashed lines) showing their proximity to the stream network (black lines).

ments compared with samples taken adjacent to the Sigmatax intake show a small deviation $\left(b=88 ; R^{2}=0.97\right)$ from unity. This deviation may be due to either each method not directly sampling the same parcel of moving water and/or due to loss of material in the transfer of water from the Sigmatax intake to the Sigmatax jar - a horizontal length of $10 \mathrm{~m}$ and a vertical height of $2 \mathrm{~m}$ - as noted in other automatic sampling methods (Clarke et al., 2009).

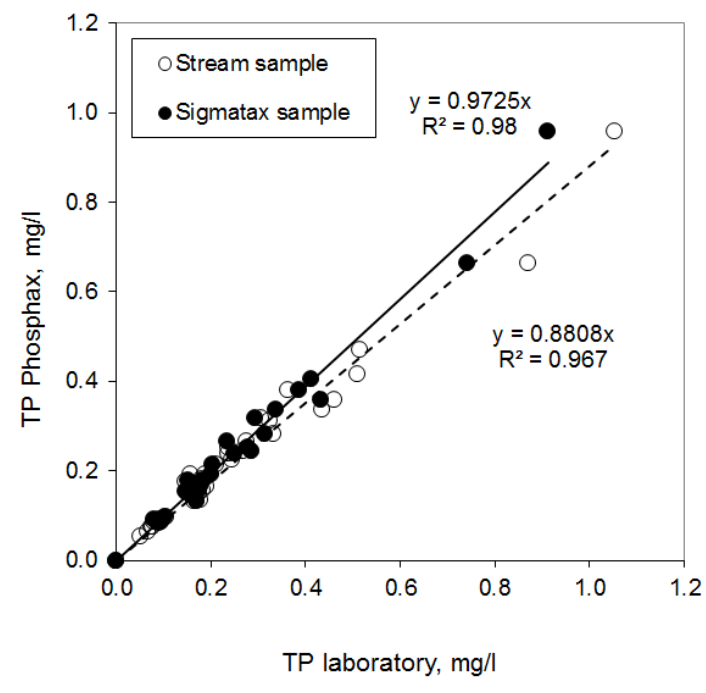

Figure 3. Quality control check on the Phosphax colorimetry process (closed symbols) and the Sigmatax sampling followed by the Phosphax colorimetry process.

\subsection{High-resolution data analysis}

There were some periods of data loss during the course of this study due to extreme weather conditions and instrument failure as a result of interruptions to power supply or breakdown (Table 3). However, up to $99 \%$ of TP records were recorded. Nevertheless, in Tyrone the final year's data ends on 21 January 2011 due to extreme freezing conditions and so this full year is incomplete for this catchment.

Despite this, the nature of the time series data of this study is of a resolution that all states of hydrological discharge, including storm flow, had been captured by the data set. This means that, within every discharge range, rising, falling and peak discharge states are integrated, with each discharge range containing several hundred data points.

The time-series discharge, TP concentration and cumulative load for both catchments (Figs. 4 and 5) clearly show the lower base flows in Co. Monaghan sub-catchment compared with Co. Tyrone and also the larger increases in cumulative TP load (in Co. Monaghan) with seasonal storms, indicative of a flashier catchment. 

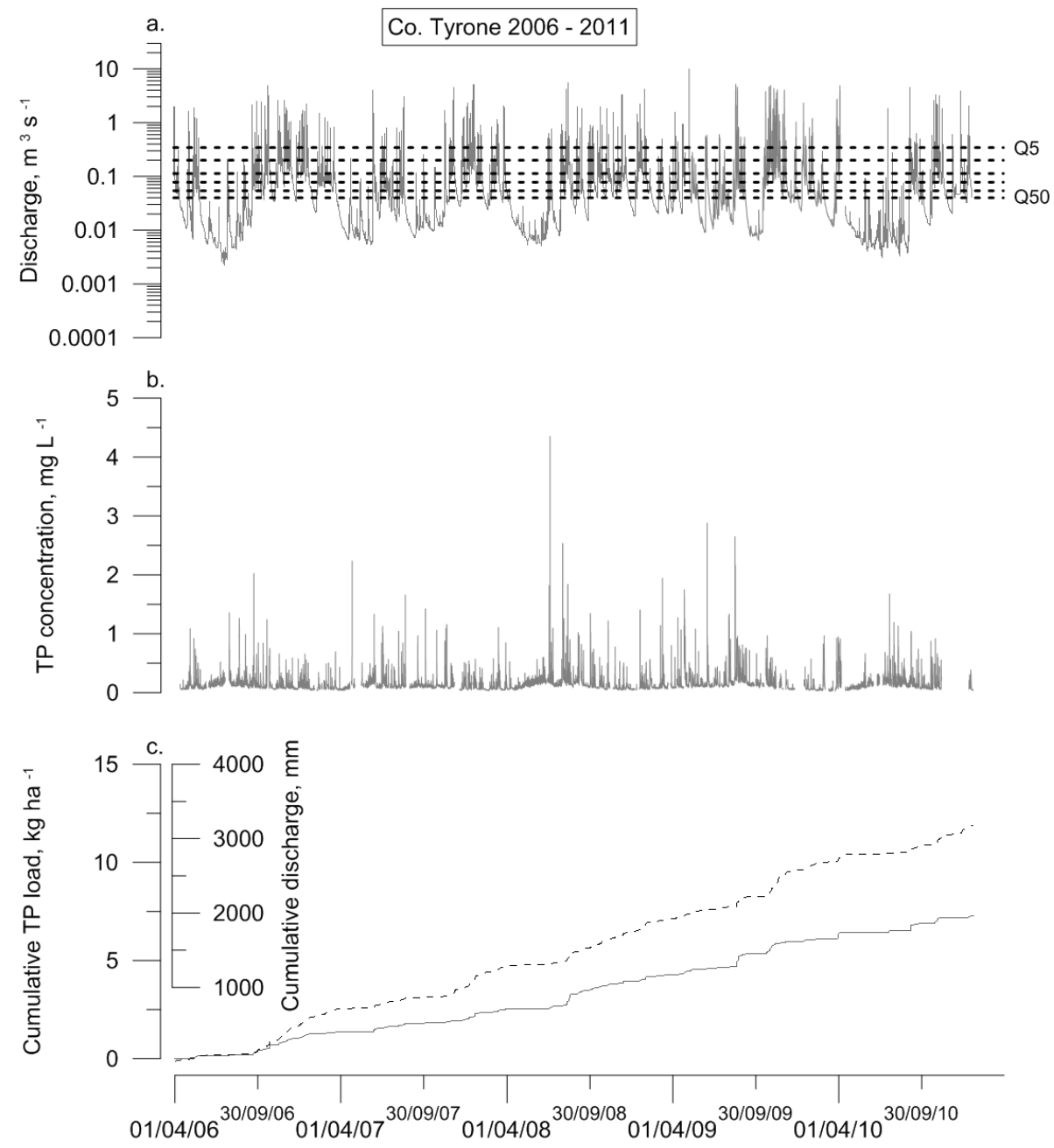

Figure 4. Time-series charts for discharge (a), TP concentration (b) and cumulative TP load and cumulative discharge (solid line) (c) from 2006-2011 in the Co. Tyrone sub-catchment. Discharge ranges $\left(Q_{50}, Q_{40}, Q_{30}, Q_{20}, Q_{10}\right.$ and $\left.Q_{5}\right)$ are shown on the discharge time series as dashed lines.

Table 3. Completeness of discharge and TP data for both catchments from 2006-2011.

\begin{tabular}{lccccc}
\hline & \multicolumn{2}{c}{$\begin{array}{c}\text { Tyrone } \\
\text { Y of data recorded for year }\end{array}$} & & \multicolumn{2}{c}{$\begin{array}{c}\text { Monaghan } \\
\text { \% of data recorded for year }\end{array}$} \\
\cline { 2 - 3 } \cline { 5 - 6 } Year & Discharge & TP & & Discharge & TP \\
\hline $2006-2007$ & 100 & 87 & & 100 & 94 \\
$2007-2008$ & 100 & 86 & & 100 & 99 \\
$2008-2009$ & 100 & 91 & & 91 & 91 \\
$2009-2010$ & 97 & 80 & & 100 & 90 \\
$2010-2011$ & 78 & 54 & & 100 & 77 \\
\hline
\end{tabular}

Flow duration curves (Fig. 6) show that the Co. Tyrone sub-catchments had consistently higher discharges than Co. Monaghan up to approximately $Q_{20}\left(0.113 \mathrm{~m}^{3} \mathrm{~s}^{-1}\right)$. Although the total annual discharges from the catchments were not significantly different $(P<0.05)$ the $\mathrm{P}$ loads in the Co. Monaghan sub-catchment were more than double those from Co. Tyrone highlighting TP concentrations differences in these similar discharges (Table 4).

For both catchments the highest TP load was in 2009/2010; in the Co. Tyrone sub-catchment this was also the year with the highest discharge but in Co. Monaghan the highest discharge was in 2006/2007, the year with the highest recorded rainfall $(1299 \mathrm{~mm})$.

Total $\mathrm{P}$ concentration, load and discharge distributions for the $Q_{40}-Q_{50}, Q_{20}-Q_{30}$ and $Q_{5}-Q_{10}$ discharge ranges over the 5 years showed that both catchments had a significant increase in TP concentration at the higher flows $\left(>Q_{10}\right)$ between 2006 and 2011, although there were some small decreases in concentrations at $Q_{40}-Q_{50}$ and $Q_{20}-Q_{30}$ in both catchments in the interim years (Table $5 \mathrm{a}$ and $\mathrm{b}$ ).

The high load from the catchments in 2009 does not appear to be linked to the frequency of high flow events, as events of $Q_{20}$ and above are no more frequent in this year than any other from 2006-2011. Additionally, the rainfall in 2009 

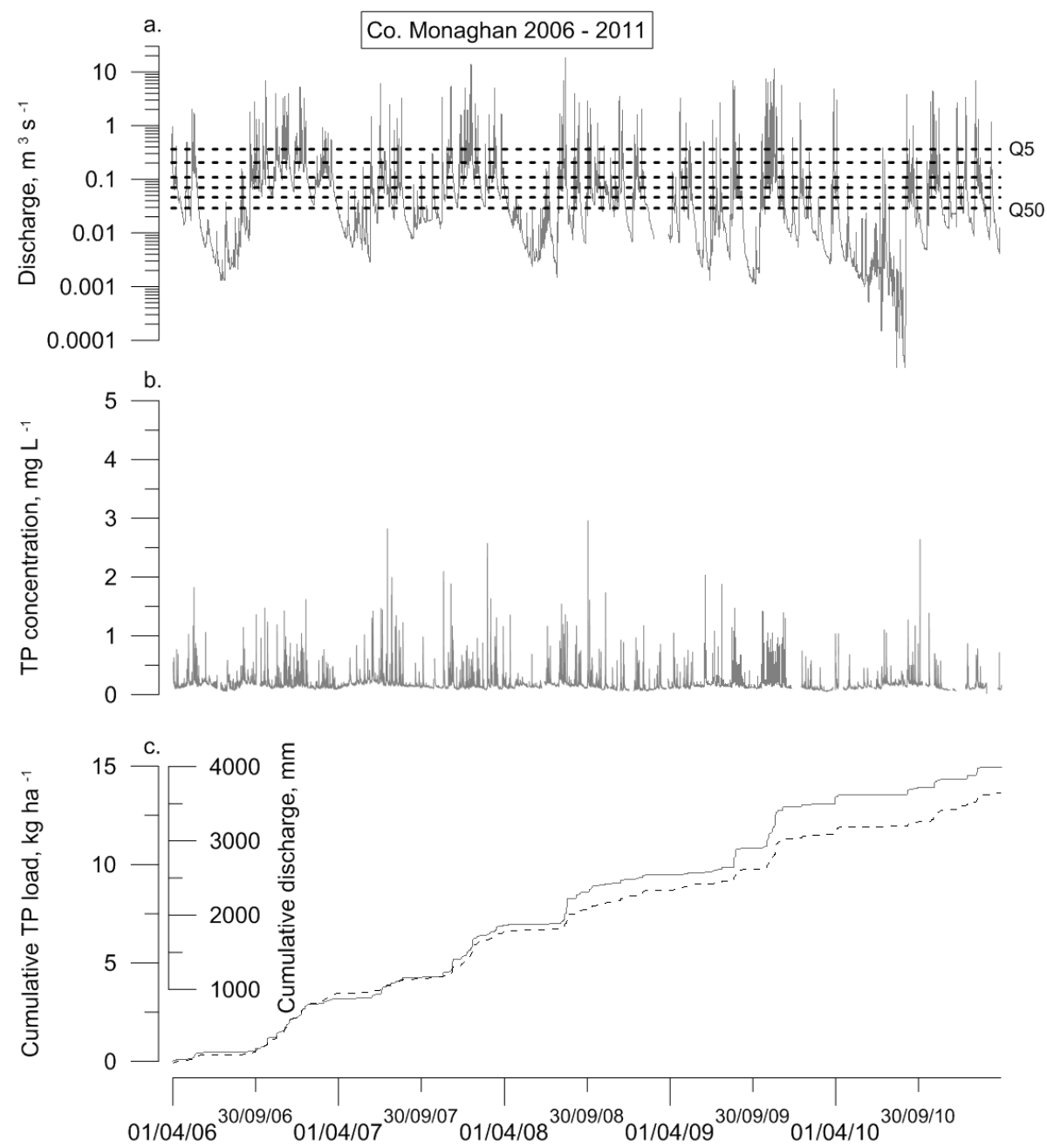

Figure 5. Time-series charts for discharge (a), TP concentration (b) and cumulative TP load and cumulative discharge (solid line) (c) from 2006-2011 in the Co. Monaghan sub-catchment Discharge ranges $\left(Q_{50}, Q_{40}, Q_{30}, Q_{20}, Q_{10}\right.$ and $Q_{5}$ are shown on the discharge time series as dashed lines.

Table 4. Annual discharge and TP load from catchments 20062011.

\begin{tabular}{lccccc}
\hline Year & \multicolumn{2}{c}{ Tyrone } & & \multicolumn{2}{c}{ Monaghan } \\
\cline { 2 - 3 } \cline { 5 - 6 } & $\begin{array}{c}\text { Discharge, } \\
\mathrm{mm}\end{array}$ & $\begin{array}{c}\mathrm{TP} \mathrm{load}, \\
\mathrm{kg} \mathrm{P} \mathrm{ha}^{-1}\end{array}$ & & $\begin{array}{c}\text { Discharge, } \\
\mathrm{mm}\end{array}$ & $\begin{array}{c}\mathrm{TP} \text { load, } \\
\mathrm{kg} \mathrm{P} \mathrm{ha}^{-1}\end{array}$ \\
\hline $2006-2007$ & 711 & 1.35 & & 944 & 3.18 \\
$2007-2008$ & 574 & 1.17 & & 828 & 3.74 \\
$2008-2009$ & 637 & 1.73 & & 564 & 2.55 \\
$2009-2010$ & 809 & 2.12 & & 814 & 3.98 \\
$2010-2011$ & 439 & 0.89 & & 494 & 1.50 \\
\hline Total & 3170 & 7.26 & 3644 & 14.94 \\
\hline
\end{tabular}

was only the second highest recorded throughout the study (1123 mm) but when the timing of the rainfall for this year was analysed it was noted that the summer of 2009 (323 mm) was considerably wetter than 2006 (209 mm). This persistent rainfall would have constantly wetted the ground and may have resulted in continued saturation of fields particularly at times of year when fields are actively managed.

Results for the low flow analysis were confounded as, although there had been a strategic replacement of four and eleven, older and potentially polluting septic tank systems in Co. Tyrone and Co. Monaghan, respectively, there had also been an increase in household density in both catchments since 2005. Co. Tyrone households had increased from 3.4 to $4.2 \mathrm{~km}^{-2}$ in 2010 and Co. Monaghan from 13.8 to $17.2 \mathrm{~km}^{-2}$ in 2010 (Arnscheidt et al., 2007; Macintosh et al., 2011).

The pair-wise comparison analysis of yearly concentrations of the low and extreme low discharges $\left(Q_{80-90}\right.$ and $Q_{90-95}$ ), in Monaghan showed there was a significant increase in TP concentration between 2006 and 2010 for $Q_{90^{-}}$ $Q_{95}$, from 0.120 to $0.148 \mathrm{mg} \mathrm{PL}^{-1}$ (Table 6). For $Q_{80}-Q_{90}$ there was a significant decrease in TP concentration between 2006 and 2010 , from 0.183 to $0.155 \mathrm{mg} \mathrm{PL}^{-1}$. The same 
Table 5. Mean TP concentrations at stated discharges ( $Q$ ranges based on Flow Duration Curve analysis) in Tyrone and Monaghan subcatchments from 2006 to 2011 showing significance of change in concentration from the initial 2006 concentration (significant at $\leq 0.05$ value).

\begin{tabular}{|c|c|c|c|c|c|c|}
\hline \multirow[t]{3}{*}{ Year } & \multicolumn{6}{|c|}{ Discharge range Tyrone } \\
\hline & \multicolumn{2}{|c|}{$Q_{40-50}$} & \multicolumn{2}{|c|}{$Q_{20-30}$} & \multicolumn{2}{|c|}{$Q_{5-10}$} \\
\hline & $\begin{array}{c}\text { Mean TP } \\
\text { concentration, } \\
\mathrm{mg} \mathrm{TPL}^{-1}\end{array}$ & $\begin{array}{l}\text { Sig. of } \\
\text { change }\end{array}$ & $\begin{array}{c}\text { Mean TP } \\
\text { concentration, } \\
\mathrm{mg} \mathrm{TPL} \mathrm{L}^{-1}\end{array}$ & $\begin{array}{l}\text { Sig. of } \\
\text { change }\end{array}$ & $\begin{array}{c}\text { Mean TP } \\
\text { concentration, } \\
\mathrm{mg} \mathrm{TPL}^{-1}\end{array}$ & $\begin{array}{l}\text { Sig. of } \\
\text { change }\end{array}$ \\
\hline \multicolumn{7}{|c|}{ (a) } \\
\hline 2006-07 & 0.094 & & 0.118 & & 0.152 & \\
\hline 2007-2008 & 0.109 & 0.503 & 0.115 & 1.000 & 0.204 & 0.001 \\
\hline 2008-2009 & 0.089 & 1.000 & 0.103 & 0.058 & 0.227 & $<0.001$ \\
\hline 2009-2010 & 0.152 & $<0.001$ & 0.162 & $<0.001$ & 0.280 & $<0.001$ \\
\hline 2010-2011 & 0.097 & 1.000 & 0.103 & 0.226 & 0.214 & 0.001 \\
\hline \multicolumn{7}{|c|}{ (b) } \\
\hline 2006-2007 & 0.190 & & 0.189 & & 0.228 & \\
\hline 2007-2008 & 0.171 & 0.026 & 0.180 & 0.575 & 0.276 & $<0.001$ \\
\hline 2008-2009 & 0.151 & $<0.001$ & 0.179 & 0.382 & 0.280 & $<0.001$ \\
\hline 2009-2010 & 0.157 & $<0.001$ & 0.208 & 0.012 & 0.391 & $<0.001$ \\
\hline 2010-2011 & 0.171 & 0.050 & 0.171 & 0.026 & 0.330 & $<0.001$ \\
\hline
\end{tabular}

Percentage of time discharge was equalled or exceeded

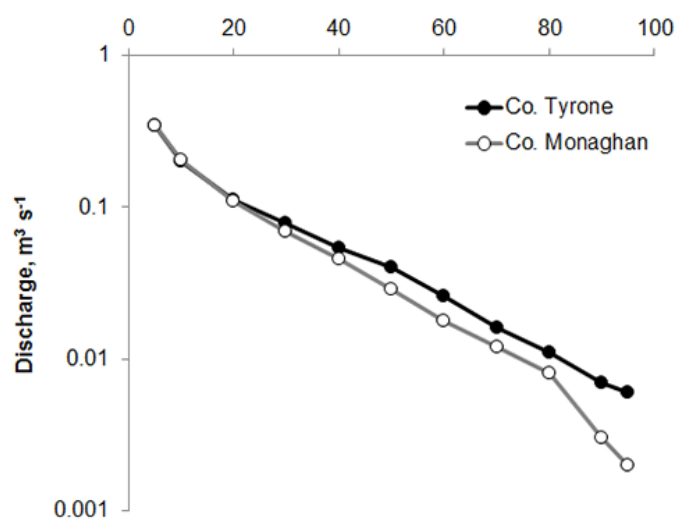

Figure 6. Flow duration curves for streams in Co. Tyrone (20062011) and Co. Monaghan (2006-2011).

analysis in Tyrone showed there was an initial significant increase between 2006 and 2008 for $Q_{90}-Q_{95}$ but no overall change between 2006 and 2010. For $Q_{80}-Q_{90}$ there was a small, significant increase from 2006 to 2010 from 0.122 to $0.133 \mathrm{mg} \mathrm{PL}^{-1}$. The changes are small and there is perhaps a risk of including instrument and sample "noise" in the comparisons; however, the comparisons are also made on filtered data based on an average of three data-points per hour which should give confidence in the statistical tests used.
Table 6. Pairwise comparisons between years for TP concentrations. The mean difference is significant at the 0.05 level $(*)$, with $\mathrm{TP}$ as the dependent variable.

\begin{tabular}{llllll}
\hline$(I)$ Year & $(J)$ Year & $\begin{array}{l}\text { Mean 95\% } \\
\text { confidence } \\
\text { difference } \\
(I-J)\end{array}$ & $(I)$ Year & $(J)$ Year & $\begin{array}{l}\text { Mean 95\% } \\
\text { confidence } \\
\text { difference } \\
(I-J)\end{array}$ \\
\hline Mon. & 2007 & $0.099^{*}$ & Tyrone & 2007 & 0.002 \\
2006 & 2008 & $0.024^{*}$ & 2006 & 2008 & $0.049^{*}$ \\
$Q_{90-95}$ & 2009 & $0.016^{*}$ & $Q_{90-95}$ & 2009 & $0.017^{*}$ \\
& 2010 & $0.028^{*}$ & & 2010 & 0.000 \\
\hline Mon. & 2007 & 0.002 & Tyrone & 2007 & $-0.018^{*}$ \\
2006 & 2008 & $-0.037^{*}$ & 2006 & 2008 & $0.027^{*}$ \\
$Q_{80-90}$ & 2009 & $-0.058^{*}$ & $Q_{80-90}$ & 2009 & $0.014^{*}$ \\
& 2010 & $-0.028^{*}$ & & 2010 & $0.010^{*}$ \\
\hline
\end{tabular}

\section{Discussion}

Soil nutrient status data is an important inventory of management within catchments (Maguire and Sims, 2002) and was one of the metrics used to assess the effectiveness of the best management practice measures for diffuse $\mathrm{P}$ mitigation throughout this study. The results from the Co. Tyrone catchment indicate that significant soil $\mathrm{P}$ source status reductions in the index 4 high risk category were achievable within the 5 -year time frame of this study and are indicative of a convergence to optimum soil $\mathrm{P}$ status (index 2 : $16-25 \mathrm{mg} \mathrm{P} \mathrm{L}^{-1}$ ) in this catchment. In Co. Monaghan the picture is less clear with an overall increase in Olsen soil $\mathrm{P}$ across all indices, 
including the high risk category. Reasons for this increase in Co. Monaghan are unclear, and, in similar catchments, further assessment may be needed on issues such as resistance to advice (Falconer, 2000), insufficient spreadlands on smaller farm holdings (Carton and Magette, 1999; Buckley and Fealy, 2012), intensification and/or land use change (Edwards and Withers, 1998; Jarvie et al., 2010).

Within both sub-catchments there appeared to be a fractured or inconsistent relationship between any changes in soil $\mathrm{P}$ nutrient status and those in run-off concentration at this time scale. Previous studies have sought to determine the relationships between input and impact; the Phosphorus Transfer Continuum concept proposed by Haygarth et al. (2005) suggests that the amount of $\mathrm{P}$ lost from soils is actually less than $5 \%$ of that applied annually and that high soil test P concentrations alone do not necessarily predict potential for loss of $\mathrm{P}$. While it is possible to improve chemical water quality almost immediately at low flows following removal of a point source input in river catchments (Jarvie et al., 2006; Withers et al., 2014), due to historic reserves of $P$ in sediments and soil, the time it will take for improvements in water quality from diffuse sources to occur may be difficult to estimate (Meals et al., 2010; Schulte et al., 2010). This fractured response is shown by assessment of the influence of changes in the sub-catchments on diffuse nutrient transfer which on the one hand did not reflect the reductions made in soil $\mathrm{P}$ status of the Co. Tyrone sub-catchment but, on the other hand, were more indicative of the soil $\mathrm{P}$ increases seen in Co. Monaghan. It may, however, be that any reductions in $\mathrm{P}$ transfer from diffuse sources have been offset by $\mathrm{P}$ losses as the result of, for example, bank erosion. A study by Kronvang et al. (2005) showed that this process could contribute 17-25\% of the P load from a catchment and so any reductions as a result of decreases in soil test $\mathrm{P}$ may not be seen.

Improvement in water quality by reducing point source inputs, although straightforward in principle, was found in this case to be more complicated in practice. Despite the mitigation measures introduced to the catchments, the $Q_{80}$ $Q_{90}$ and $Q_{90}-Q_{95}$ results in Counties Tyrone and Monaghan suggest that few improvements to point source inputs to the streams have taken place. Whether this is due to the improvements not including the STSs which were actually those impacting on the streams, or additional systems offsetting any improvements which would otherwise have taken place, is hard to determine.

Arnscheidt et al. (2007) stated that there was a significant correlation in the two catchments between STS condition and density, and low flow TP concentration. The increase in STS density in Tyrone from 3.4 to $4.6 \mathrm{~km}^{-2}$ may, therefore, have had some impact on the $\mathrm{P}$ concentrations in the catchment during the post mitigation period. Despite the Monaghan tank density also increasing, from 13.8 to $17.2 \mathrm{~km}^{-2}$, there was no significant increase in TP concentration.

Changes in the overall annual sub-catchment TP loads as a result of any improvements to STSs would not be expected to be significant in this study as the changes which could potentially be achieved would be too small.

Although it was proposed that annual TP load would not be the optimum metric for assessing change in catchment water quality, it is, however, a useful measure when comparing catchment with catchment. For example, TP loads from the grassland catchments of this study were 0.89 to $2.12 \mathrm{~kg} \mathrm{Pha}^{-1}$ and 1.50 to $3.98 \mathrm{~kg} \mathrm{Pha}^{-1}$, in Co. Tyrone and Co. Monaghan, respectively. These are high in relation to two arable catchments in Ireland reported by Melland et al. (2012) which had TP loads ranging from 0.12 to $0.83 \mathrm{~kg} \mathrm{Pha}^{-1}$ but are similar to TP loads observed in Danish arable catchments by Kronvang et al. (2005) which ranged from 0.5 to $5.8 \mathrm{~kg} \mathrm{Pha}^{-1}$. Both sub-catchments of this study are the same area $\left(5 \mathrm{~km}^{2}\right)$ yet it is clear from the results that the loads from Co. Monaghan are consistently almost double those from Co. Tyrone - even accounting for missing data in the last year of the study.

High soil test $\mathrm{P}$ concentration in near stream fields is known to impact on $\mathrm{P}$ transfers to the stream during rainfall events which cause overland and sub-surface flow (Gburek, 2000). GIS analysis showed that the Co. Monaghan subcatchment had a larger percentage of high index fields $(\geq 4)$ and also a greater length stream network adjacent to these fields (Fig. 2a and b). These fields, which can be classified as CSAs using the broadest definition (high soil $\mathrm{P}$ and low flow-path length) (McDowell and Sharpley, 2003), may have been the source of the higher load delivery in the Co. Monaghan catchment. The Co. Monaghan catchment was also determined to be flashier than Co. Tyrone, having lower base flows and periodically higher storm flows. The longer stream length in the Co. Monaghan sub-catchment would also increase risk of P transfer from bank erosion (Kronvang et al., 2005)

Although CSAs are now being recognised as major sources of nutrient and other pollutant transfers from land to water they are not specifically targeted within any of the directives pertaining to the Water Framework Directive or daughter directives at least at farm and field scale (Wall et al., 2012). This omission is also critically reviewed in more recent studies (Doody et al., 2012; Thompson et al., 2012).

The increased source and transport pressures from the Co. Monaghan sub-catchment can, therefore, be determined as a main factor in the increased load from this catchment. In order to reduce these pressures, and therefore the potential for loss, a policy of reducing inputs should be continued. Indeed, the P regulations in both Irish jurisdictions do promote, inter alia, convergence to optimum soil P ranges. In support of the policy, a long term catchment study in Norway showed that a reduction in $\mathrm{P}$ inputs as a result of change in soil management could produce a decrease in run-off $\mathrm{P}$ concentration with time; although there could be a considerable time lag between implementation and improvements from $P$ saturated soils (Bechmann et al., 2008) and this is noted by Schulte et al. (2010) for Irish soils. However, even with a reduction 
in source pressure, the flashier hydrology of the Co. Monaghan catchment will likely continue to drive nutrient transfers more so than Co. Tyrone. This was also noted in similar catchments by Jordan et al. (2012), and will most likely mean that lag effects will be longer.

The two wettest years were $2006(1299 \mathrm{~mm})$ and 2009 $(1123 \mathrm{~mm})$ with the latter associated with the highest TP loads but with the summer of 2009 being more than $50 \%$ wetter than 2006. When the timing of the rainfall events in both years, 2006 with the most storms and 2009 with the highest loads, was analysed it was determined that the majority of major storm events $\left(>Q_{5}\right)$ in 2006 occurred between 30 October and the 30 January, with no storm discharges at all between May and September of that year; only $4 \mathrm{~h}$ of $Q_{5}$ discharges were recorded in the Co. Monaghan subcatchment outside of this period for this year. In 2009, however, there were frequent $Q_{5}$ flows throughout the summer with the maximum flow for Tyrone for that year recorded on 20 August $\left(5.2 \mathrm{~m}^{3} \mathrm{~s}^{-1}\right)$. The small percentage of $Q_{95}$ flows for this year, especially in the Co. Tyrone sub-catchment, indicated that run-off from the land was sufficient to maintain the stream above extreme (5-year) baseflow for over $99 \%$ of the year. This is indicative of there being sufficient precipitation to maintain fields in a constantly wetted state throughout the year.

The Co. Tyrone and Co. Monaghan sub-catchment response in 2009 to this persistent rainfall throughout the entire year resulted in the highest TP load and also, importantly, the highest TP concentration for the $Q_{5-10}$ discharges over the 5 years. From this the data indicate that antecedent weather conditions can add to the potency of any rainfall event's impact on catchment water quality at subsequently higher discharges (as proposed by Kirchner et al., 2004; Neal et al., 2012). This finding adds to previous studies (Turner and Haygarth, 2001; Styles and Coxon, 2006) where, at laboratory scale, dry soils when wetted were found to release more TP than persistently wet soils. However, this study showed that at larger scales, and in these particular catchments, already wet soil has greater potency for TP transfer during storm events. This is due to sustained wetting (prolonged events maintaining saturation excess flows and an increase in effective rainfall) and, in particular, during periods which may coincide with nutrient management and incidental losses during the summer.

\section{Conclusions}

This study used high-resolution TP monitoring in two catchment streams to assess changes in two principle source pressures over a 5-year period (2006-2011); diffuse source pressure changes allied to high soil $\mathrm{P}$ and rural point source pressures relating to STS changes. The findings were that:

- There were inconsistent changes in high soil $\mathrm{P}$ status between catchments with one showing an increase in high soil P fields and the other a convergence towards optimum, despite similar soil nutrient management advice.

- Despite changes in STS pressure, companion work indicated an overall increase in STS pressure due to newbuilds during the study period.

- There were inconsistent, or fractured, responses between changes in soil $\mathrm{P}$ pressure, point source pressure and $\mathrm{P}$ delivered during both high and low flow periods as analysed in the high-resolution TP concentration data set. None of the analysis for TP delivered indicated that decreased high soil $P$ pressures (in one catchment) had made an impact on water quality; more so, the apparent increase in soil $\mathrm{P}$ pressure in the other catchment, and offset or increased STS pressures in both catchments, appeared to be more reflected in the high-resolution TP data set.

- The diffuse source pressures in one catchment were found to be higher than the other catchment due to a higher magnitude of high soil $\mathrm{P}$ fields adjacent to water courses coupled with a flashier run-off regime. This lead to consistently double the annual TP load, despite similar sized catchments, soil type and land use.

- The potency of TP loss in any similar discharge range between years was found to be reflective of antecedent conditions with already wet soils delivering more $\mathrm{P}$ per unit discharge than similar discharges following drier conditions. At least some of this loss may have been due to incidental $\mathrm{P}$ pressures during the summer but highlights wet summers as being particularly vulnerable to $P$ loss and perhaps offsetting the response of other catchment mitigation measures.

This study shows the utility of high-resolution water quality analysis in the short to medium term for studying changes in both catchment pressures and response. It also firmly suggests that the short to medium term is an inappropriate time scale to gauge both the capacity of policy to influence a catchment change and also for that change to be detected in metrics of water quality.

Acknowledgements. We acknowledge the contribution of Rachel Cassidy (formerly University of Ulster) Queen's University, Belfast, for undertaking Monte-Carlo analysis for soil re-sampling. We also acknowledge Dr Suzanne Higgins (formerly University of Ulster), Agri-Food Biosciences Institute (AFBI), Belfast, for access to the 2005 soil P data set. We thank Hugo McGrogan and Pete Devlin for technical help with the water and soil sampling work and catchment farmers for access to land. This research was funded by the Special European Programmes Board under INTERREG IIIA (020204 - Blackwater TRACE), Northern Ireland Environment Agency, Lisburn, Irish Environmental Protection Agency, Dublin, and a Department of Employment and Learning (Northern Ireland) PhD scholarship. 
Edited by: B. Kronvang

\section{References}

Agbenin, J. O. and Tiessen, H.: Phosphorus sorption at field capacity and soil ionic strength: Kenetics and transformation, Soil Sci. Soc. Am. J., 59, 998-1005, 1995.

Arnscheidt, J., Jordan, P., Li, S., McCormick, S., McFaul, R., McGrogan, H. J., Neal, M., and Sims, J. T.: Defining the sources of low-flow phosphorus transfers in complex catchments, Sci. Total Environ., 382, 1-13, 2007.

Bechmann, M., Deelstra, J., Stalnacke, P., Eggestad, H. O., Øygarden, L., and Pengerud, A.: Monitoring catchment scale agricultural pollution in Norway: policy instruments, implementation of mitigation methods and trends in nutrient and sediment losses, Environ Sci. Policy, 11, 102-114, 2008.

Bowes, M. J., Smith, J. T., Jarvie, H. P., and Neal, C.: Modelling of phosphorus inputs to rivers from diffuse and point sources, Sci. Total Environ., 395, 125-138, 2008.

Bowes, M. J., Smith, J. T., and Neal, C.: The value of highresolution nutrient monitoring: A case study of the River Frome, Dorset, UK, J. Hydrol., 378, 82-96, 2009.

Buckley, C. and Fealy, R.: Intra-national importation of pig and poultry manure, Int. J. Agr. Manage., 1, 41-47, 2012.

Carton, O. T. and Magette, W. L.: The implications of Irish legislationand regulations for the land spreading of manures from intensive agricultural enterprises, Teagasc, Dublin, Ireland, 1999.

Cassidy, R. and Jordan, P.: Limitations of instantaneous water quality sampling in surface-water catchments: Comparison with nearcontinuous phosphorus time-series data, J Hydrol., 405, 182193, 2011.

Cherry, K. A., Shepard, M., Withers, P. J. A., and Mooney, S. J.: Assessing the effectiveness of actions to mitigate nutrient loss from agriculture: A review of methods, Sci. Total Environ., 406, $1-23,2008$.

Clarke, S. E., Siu, C. Y. S., Pitt, R., Roenning, C. D., and Treese, D. P.: Peristaltic pump autosamplers for solids measurement in stormwater runoff, Water Environ Res., 81, 192-200, 2009.

Criuckshank, J. G.: Soil and Environment: Northern Ireland, DANI/QUB., Belfast, 1997.

Donn, M. J., Barron, O. V., and Barr, A. D.: Identification of phosphorus export from low-runoff yielding areas using combined application of high frequency water quality data and MODHMS modelling, Sci. Total Environ., 426, 264-272, 2012.

Doody, D. G., Archbold, M., Foy, R. H., and Flynn, R.: Approaches to the implementation of the Water Framework Directive: Targeting mitigation measures at critical source areas of diffuse phosphorus in Irish catchments, J. Environ. Manage., 93, 225-234, 2012.

Douglas, R. W., Menary, W., and Jordan, P.: P and sediment transfers in a grassland river catchment, Nutr. Cy. Agroecosyst., 77, 199-212, 2007.

Edwards, A. C. and Withers, P. J. A.: Soil phosphorus management and water quality: a UK perspective, Soil Use Manage., 14, 124 130, 1998.
Edwards, A. C. and Withers, P. J. A.: Linking phosphorus sources to impacts in different types of waterbody, Soil Use Manage., 23, 133-143, 2007.

Eisenreich, S. J., Bannerman, R. T., and Armstrong, D. E.: A simplified $\mathrm{P}$ analysis technique, Environ. Lett., 9, 43-53, 1975

Falconer, K.: Farm-level constraints on agri-environmental scheme participation: a transactional perspective, J. Rural Stud., 16, 379394, 2000.

Gburek, W. J., Sharpley, A. N., Heathwaite, L., and Folmar, G. J.: Phosphorus management at the watershed scale: A modification of the phosphorus index, J. Environ. Qual., 29, 130-144, 2000.

Greene, S., Taylor, D., McElarney, Y. R., Foy, R. H., and Jordan, P.: An evaluation of catchment-scale phosphorus mitigation using load apportionment modelling, Sci. Total Environ., 409, 2211 2222, 2011.

Griffiths, D.: Effects of climatic change and eutrophication on the glacial relict, Mysis relicta, in Lough Neagh, Freshwater Biol., 52, 1957-1967, 2007.

Harris, G. P. and Heathwaite, A. L.: Why is achieving good ecological outcomes in rivers so difficult?, Freshwater Biol., 57, 91-107, 2012.

Haygarth, P. M., Condron, L. M., Heathwaite, A. L., Turner, B. L., and Harris, G .P.: The phosphorus transfer continuum: Linking source to impact with an interdisciplinary and multi-scaled approach, Sci. Total Environ., 344, 5-14, 2005.

Hirsch, R. M.: Flux of nitrogen, phosphorus, and suspended sediment from the Susquehanna River Basin to the Chesapeake Bay during Tropical Storm Lee, September 2011, as an indicator of the effects of reservoir sedimentation on water quality, USGS Scientific Investigations Report 5185, USGS, USA, p. 17 , 2012.

Jarvie, H. P., Neal, C., and Withers, P. J. A.: Sewage-effluent phosphorus: A greater risk to river eutrophication than agricultural phosphorus?, Sci. Total Environ., 360, 246-253, 2006.

Jarvie, H. P., Withers, P. J. A., Bowes, M. J., Palmer-Felgate, E. J., Harper, D. M., Wasiak, K., Wasiak, P., Hodgkinson, R. A., Bates, A., Stoate, C., Neal, M., Wickham, H. D., Harman, S. A., and Armstrong, L. K.: Streamwater phosphorus and nitrogen across a gradient in rural-agricultural land use intensity, Agr. Ecosyst. Environ., 135, 238-252, 2010.

Jordan, P., Arnscheidt, J., McGrogan, H., and McCormick, S.: Highresolution phosphorus transfers at the catchment scale: the hidden importance of non-storm transfers, Hydrol. Earth Syst. Sci., 9, 685-691, doi:10.5194/hess-9-685-2005, 2005a.

Jordan, P., Menary, W., Daly, K., Kiely, G., Morgan, G., Byrne, P., and Moles, R.: Patterns and processes of phosphorus transfer from Irish grassland soils to rivers - integration of laboratory and catchment studies, J. Hydrol., 304, 20-34, 2005 b.

Jordan, P., Arnscheidt, A., McGrogan, H., and McCormick, S.: Characterising phosphorus transfers in rural catchments using a continuous bank-side analyser, Hydrol. Earth Syst. Sci., 11, 372 381, doi:10.5194/hess-11-372-2007, 2007a.

Jordan, C., Higgins, A., and Wright, P.: Slurry acceptance mapping of Northern Ireland for run-off risk assessment, Soil Use Manage., 23, 245-253, 2007b.

Jordan, P., Melland, A. R., Mellander, P., Shortle, G., and Wall, D.: The seasonality of phosphorus transfers from land to water: Implications for trophic impacts and policy evaluation, Sci. Total Environ., 434, 101-109, 2012. 
Kane, D.: Hydrograph seperation using end member mixing models in the Oona water river catchment, Co. Tyrone, PhD Edn., University of Ulster, Ulster, 2009.

Kirchner, J. W., Feng, X., Neal, C., and Robson, A. J.: The fine structure of water-quality dynamics: the (high-frequency) wave of the future, Hydrol. Process., 18, 1353-1359, 2004.

Knight, J., McCarron, S. G., and McCabe, A. M.: Landform modifications by paleao ice streams in east central Ireand, Ann. Glaciol., 28, 161-167, 1999.

Kronvang, B., Bechmann, M., Lundekvam, H., Behrendt, H., Rubaek, G. H., Schoumans, O. F., Syversen, N., Andersen, H. E., and Hoffmann, C. C.: Phosphorus Losses from Agricultural Areas in River Basins: Effects and Uncertainties of Targeted Mitigation Measures, J. Environ. Qual., 34, 2129-2144, 2005.

Kronvang, B., Audet, J., Baattrup-Pedersen, A., Jensen, H., and Larsen, S.: Phosphorus Load to Surface Water from bank erosion in a Danish Lowland River Basin, J. Environ. Qual., 41, 304-313, 2012.

Lloyd, C. E. M., Freer, J. E., Collins, A. L., Johnes, P. J., and Jones, J. I.: Methods for detecting change in hydrochemical time series in response to targeted pollutant mitigation in river catchments, J. Hydrol., 514, 297-312, 2014.

Macintosh, K. A., Jordan, P., Cassidy, R., Arnscheidt, J., and Ward, C.: Low flow water quality in rivers; septic tank systems and high-resolution phosphorus signals, Sci. Total Environ., 412413, 58-65, 2011.

MAFF: Fertiliser Recommendations for Agricultural and Horticultural Crops (RB209), RB209 Edn., The Stationary Office, London, UK, 2000.

Maguire, R. O. and Sims, J. T.: Measuring agronomic and environmental soil phosphorus saturation and predicting phosphorus leaching with Mehlich 3, Soil Sci. Am. J., 66, 2033-2039, 2002.

Meals, D. W., Dressing, S. A., and Davenport, T. E.: Lag time in water quality response to best management practices: A review, J. Environ Qual., 39, 85-96, 2010.

McDowell, R. W. and Sharpley, A. N.: Phosphorus solubility and release kinetics as a function of soil test $\mathrm{P}$ concentration, Geoderma, 112, 143-154, 2003.

Melland, A. R., Mellander, P., Murphy, P. N. C., Wall, D. P., Mechan, S., Shine, O., Shortle, G., and Jordan, P.: Stream water quality in intensive cereal cropping catchments with regulated nutrient management, Environ. Sci. Policy, 24, 58-70, 2012.

Morgan, M. F.: Chemical Soil Diagnosis by the Universal Soil Testing System, Connecticut Agricultural Experimental Station Bulletin, 450, New Haven, CT, 1941.

Neal, C., Reynolds, B., Rowland, P., Norris, D., Kirchener, J. W., Neal, M., Sleep, D., Lawlor, A., Woods, C., Thacker, S., Guyatt, H., Vincent, C., Hockenhull, K., Wickham, H., Harman, S., and Armstrong, L.: High-frequency water quality time series in precipitation and streamflow: From fragmentary signals to scientific challenge, Sci. Total Environ., 434, 3-12, 2012.

O'Dochairtaigh, B. E.: The Oona water catchment: Trial Groundwater Body Characterisation for Water Framework Directive Implementation, BGS, 45 pp., 2003.

OJEC - Official Journal of the European Communities: Establishing a Framework for Community Action in the Field of Water Policy, Water Framework Directive, 2000/60/EC, Brussels, 2000.
Olsen, S. R., Cole, C., Watanabe, F. S., and Dean, L.: Estimation of available phosphorus in soils by extraction with sodium bicarbonate, US Department of Agriculture, Washington, D.C., 1954.

Palmer-Felgate, E. J., Jarvie, H. P., Williams, R. J., Mortimer, R. J., Loewenthal, M., and Neal, C.: Phosphorus dynamics and productivity in a sewage-impacted lowland chalk stream, J. Hydrol., 351, 87-97, 2008.

Schulte, R. P. O., Melland, A. R., Fenton, O., Herlihy, M., Richards, K., and Jordan, P.: Modelling soil phosphorus decline: Expectations of Water Framework Directive policies., Environ. Sci. Policy, 13, 472-484, 2010.

Sharpley, A. N. and Reikolainen, S.: Phosphorus in agriculture, in: Phosphorus loss from soil to water, 1st Edn., edited by: Tunney, H., CAB International, New York, 1997.

SRNI 488 - Statutory Rules Northern Ireland 488, Phosphorus (Use in Agriculture) Regulations (Northern Ireland): Department of the Environment Northern Ireland, Belfast, p. 8, 2006.

Styles, D. and Coxon, C.: Laboratory drying of organic-matter rich soils: Phosphorus solubility effects, influence of soil characteristics, and consequences for environmental interpretation, Geoderma, 136, 120-135, 2006.

Thompson, J. J. D., Doody, D. G., Flynn, R., and Watson, C. J.: Dynamics of critical source areas: Does connectivity explain chemistry?, Sci. Total Environ., 435-436, 499-508, 2012.

Turcotte, D. L.: Fractals and chaos in geology and geophysics, 2nd Edn., Cambridge University Press, Cambridge, 1997.

Turner, B. L. and Haygarth, P. M.: Phosphorus mobilisation in rewetted soils, Nature, 411, 258, 2001.

Wade, A. J., Palmer-Felgate, E. J., Halliday, S. J., Skeffington, R. A., Loewenthal, M., Jarvie, H. P., Bowes, M. J., Greenway, G. M., Haswell, S. J., Bell, I. M., Joly, E., Fallatah, A., Neal, C., Williams, R. J., Gozzard, E., and Newman, J. R.: Hydrochemical processes in lowland rivers: insights from in situ, highresolution monitoring, Hydrol. Earth Syst. Sci., 16, 4323-4342, doi:10.5194/hess-16-4323-2012, 2012.

Wall, D., Jordan, P., Melland, A. R., Mellander, P., Buckley, C., Reaney, S. M., and Shortle, G.: Using the nutrient transfer continuum concept to evaluate the European Union Nitrates Directive National Action Programme, Environ. Sci. Policy, 14, 664-674, 2011.

Wall, D. P., Murphy, P. N. C., Melland, A. R., Mechan, S., Shine, O., Buckley, C., Mellander, P.-E., Shortle, G., and Jordan, P.: Evaluating nutrient source regulations at different scales in five agricultural catchments, Environ. Sci. Policy, 24, 34-43, 2012.

Watson, C. J., Smith, R. V., and Matthews, D. I.: Increase in phosphorus losses from grassland in response to olsen-P accumulation, J. Environ Qual., 36, 1452-1460, 2007.

Withers, P. J. A., May, L., Jarvie, H. P., Jordan, P., Doody, D., Foy, R. H., Bechmann, M., Cooksley, S., Dils, R., and Deal, N.: Nutrient emissions to water from septic tank systems in rural catchments: Uncertainties and implications for policy, Environ. Sci. Policy, 24, 71-82, 2012.

Withers, P. J. A., Jordan, P., May, L., Jarvie, H. P., and Deal, N. E.: Do septic tank systems pose a hidden threat to water quality?, Front. Ecol. Environ., 12, 123-130, 2014. 